\title{
Provincial Theatre: Problems of Establishment and Development of Performing (Dramatic) Art in Khabarovsk
}

\author{
Sergey V. Listopadov* \\ Khabarovsk State Institute of Culture \\ 112 Krasnorechenskaia Str., Khabarovsk, 680045, Russia
}

Received 12.02.2016, received in revised form 28.02.2016, accepted 18.04.2016

The article is devoted to the peculiarities of the provincial theater establishment and development. Problems mentioned in the article are considered through the example of the theatre arts in the city of Khabarovsk in general and through the example of Khabarovsk Regional Theater of Drama and Comedy in particular. The author comes to conclusion that establishment of professional theatrical environment in Khabarovsk in 1952 laid the foundation on which drama theatre is still based today, with its unique features in direction and acting work development.

Keywords: art, theatre, provincial theatre, drama theatre, direction, repertoire.

DOI: 10.17516/1997-1370-2016-9-6-1391-1398.

Research area: art history.

The fundamental principles of any theater development, including a deeply provincial one are, firstly, the establishment of a strong artistic and aesthetic and organizational and staging directing; secondly the principle of harmonious and well thought-out repertoire policy, which, in the author's opinion, cannot exist in isolation from the first one. These points are supported by specific historical facts that took place in the biography of the Theatre of Drama. In autumn 1962 the theater collective headed by a new art director - stage director, the Honoured Artist of the Armenian SSR Yan Tsitsinowski, manysided personality and a good professional, who succeeded in bringing a high level of professionalism to the Khabarovsk Theatre of Drama direction, so that even capital city press spoke about the theater. And the reason for that was a great success of guest performances that took place in Moscow in the Maly Theater.

But before considering the material concerning the origin and development of the provincial theater art of direction, it is necessary to analyze the history of the theatre business in the city and in the region as a whole in detail. To look through all the tendencies and direction of creative thought in the period that started at the origin of theater activities and ended by the formation of professional theater with a permanent troupe and art direction. Only such

(C) Siberian Federal University. All rights reserved

* Corresponding author E-mail address: listopadovs@mail.ru 
a retrospective and a basis for the analysis of our subject seems necessary and correct, as provincial theater as a concept to a large extent is a particular, special history, some details and the whole characteristics of which happen to be relevant to the present.

Life of the theatre is inseparable from the life of the city. Khabarovsk dwellers can be proud of the fact that a few years after the foundation stone was laid in Khabarovsk (originally - a military post of Khabarovsk), the first theatrical season started in the city. Nowadays dramatic historians and theater art lovers know the names of M.F. Knauf-Kaminskaya, M.V. Vasilyeva, P.S. Stanislavskay (Blagoveshchensk), V.V. Talzatti, E.F. Morelli (Vladivostok), R.A. Kurchaev, Marks-Kurchaeva (Irkutsk) and two amateur actors from Khabarovsk - I.N. Fomin and L.M. Vol'skaya. The history of theatrical arts development in Khabarovsk - a small settlement on the distant outskirts of Russia started with them.

In 1897 in Khabarovsk "... there were a lot of intellectuals on the population of 10000 people" (Teatr i iskusstvo, 1897). Educated population employed in the administrative and teaching work, numerous officers off duty and service sought for communion and customary entertainment, wanted, as well as in the capital from which many of them came, to visit the theater. Boxoffice receipts of the Public Meeting room, where initially all the performances, including drama performances, took place, reached quite large amounts here (up to 500 rubles), in addition, a small group of actors could stay in this city for a whole winter and earn 18 thousand rubles a season for two performances in week. From the local press publications of that time it can be concluded that the room for the performances in the city was not very good, with a folding platform where it was impossible to use the orchestra because there was no space in front of the stage. But visiting booking agents found a way out of this situation: they organized the musicians play during the intervals. It was comfortable to accompany here on the piano standing in the lobby.

The interest of the people who lived in Khabarovsk to the theater and other forms of performing arts in the last decade of the $19^{\text {th }}$ - the first decade of $20^{\text {th }}$ centuries was large enough. After all, "life here is undistinguished and silent, that is why Khabarovsk dwellers have very warm attitude towards the theater" (Teatr i iskusstvo, 1897).

But with all this, it is necessary to mention the fact that since the beginning of the theater in the Far East, the remoteness from the center, as well as severe weather conditions were evident and negative factor that hindered the development of the theater here.

Khabarovsk was actively visited by various troupes. The quality of their staging and performances were different. Some of them had quite responsible attitude to their activities, while others, letting things take their course, were just trying to make some money from the unsophisticated perception of such performances by the theater audience.

The first autumn-winter theater season was opened in Khabarovsk by "The Association of Drama and Opera Performers" led by M.F. Knauf-Kaminskaya and M.V. Vasilyev. It was on 12 (24) October 1894. Operetta by J. Offenbach "La Périchole" was shown that evening (Ivanov, 1994).

It should be mentioned again that initially the city did not have enough equipped theater room and was served by a not very good, poorly adapted building of Mr. Mateus' circus. It was only later when "the circus at the initiative of artists Voronin and Tabentskoi in 1906 was rebuilt into a theater and since then it is alternately occupied by dramatic and operetta troupes" (Teatr i iskusstvo, 1909). 
Booking agents varied and touring troupes alternated - only affection of Khabarovsk dwellers to performing arts remained constant.

It should be noted that there were successful leaders among visiting booking agents. The winter season of 1907-1908 and Non-repertory Company by V.V. Kumel'sky can be an example.

In this season Khabarovsk had a very good and reputable troupe. Al'ianova, Barskaya, Verina, Kazimovskaya, Leonova, Petrova, Rozen, Slavskaya-Smirnova, Cherniavskaya and Khrushcheva were among dramatic actresses. The following actors were recruited: Besh'ev, Volgin, Zarin, Istomin, Kononenko, Kravtsov, Kul'ma, Kumel'sky-Lirov, Mamonov, Ryabov Teplov, Trotsky and Tuganov-Cherniavsky. V.V. Kumel'sky was a director.

Here it is proposed to pay attention to the first mentioning of the creative leader in the Khabarovsk theatre world. That is, already nonrepertory company's performances had active basis in their artistic principle represented by arising, albeit still unprofessional, not yet "strong" direction.

The question of what should we mean by "strong" direction is in the heart of the theoretical and methodological foundations of this article.

"Strong" direction of a theater without inverted commas, that is explicatedly and clearly can be represented in several characteristics, the most important of which are:

1) real professionalism of individual directors who in a certain period of time are engaged in staging activities in the theater;

2) at the same time individuality and some artistic principles of each director, with who a specific period of a particular theater development is associated with;

3) general artistic methodological framework of the directing team of the theater - whether it is a traditional psychological theater, or a modernist theater, whether it is a spectacular folk theater, or a romantic theater, etc.;

4) "strong" direction should be based on one of the previous directing schools (otherwise there won't be a purpose of development, that is, it will not create its own directing school).

Thus, returning to V.V. Kumel'sky's Nonrepertory Company, positive tendencies in the development of theatrical art should be noted. The plays of this Non-repertory Company were staged with the ensemble and were staged well. The material success was very good. Individual performers started to stand out in the general ensemble. Actress Al'ianova, Rozen and Cherniavskaya, actors Kumel'sky, Zorin, Kravtsov, Kul'min and Teplov enjoyed great success.

"The repertoire was the most varied, from the new plays "Black Ravens" for 4 ordinary performances brought about 4 thousand (which was unheard of in Khabarovsk)" (Teatr i iskusstvo, 1908).

All creative activity in Khabarovsk troupes was so unstable that it is very difficult to single out any particular system of the theater business growth and development. Too much in the quality of performance depended on the creative cleanliness of the stage actors, directors and artists, what, in general, is still relevant today. The modern provincial theater also requires a strong art direction, based on the artistic-aesthetic and organizational-staging principles.

Even before 1917, there were preconditions for the emergence of a real, strong theater in the city of Khabarovsk, but it was hampered by a number of circumstances that were in many ways similar to the modern problems of the province:

1) "theater - audience" relationships were rather ambivalent and unstable than strong, there was no genuine dialogue in this relationships;

2) Khabarovsk theatre troupes (non-repertory companies) had neither clear repertoire policy, 
nor even any principle in selecting pieces for staging, most likely non-repertory Khabarovsk theater used the simplest "trial and error" method in the repertoire selection;

3) pre-revolutionary Khabarovsk Theatre of Drama lived under condition of fierce competition that did not contribute to its creative growth, and as a result not creative methods of competition, restraining it. “... The performance was quite decent, there finally even too much genuine "theater audience". But theatrical figures, up to that time apparently had not yet found modus vivendi, which unites audience with the theater and pushes theater to the sphere of public intellectual life of the city. Probably by this, it is possible to explain the fact that there were evenings, when the number of spectators in the theaters did not exceed ... 50 people. Nonrepertory company could not interest the public the repertoire was extremely unprincipled: there were both "Anathema" and a cheap popular "Stenka Razin", "Ermak Timofeevich" next to "Elga" by Hauptmann. Competition here was very fierce: in one and the same evening the same new play was staged in the theater at the same time. The result - performances in rush, distrust of the audience and - empty theater .... And you think: there were so many financial geniuses in Siberia in rail, timber and other industries, and it didn't occur to anyone from the wealthy theatrical figures to put theatrical life on our Far East in order, even with the capitalist tendencies" (Teatr $\mathrm{i}$ iskusstvo, 1910).

When Soviet government took power in Khabarovsk, as well as in other cities of the country, such institutions as young workers theaters, propaganda theaters and "people's", i. e. amateur theater groups appeared. This time dictated the trend. It was the time when the temple of Melpomene turned into one of the instruments of ideological struggle. But it was in this period when new tendencies in the theater as a whole and in the director's profession, which got a rise started developing. The search for the moments combining in the form and the content of dramatic productions started. It theatrical experiment began. Soviet power was not just interested in the theater, but also, of course, because of its totalitarian nature, the desire for complete control over art and turning it into one of their ideological tools, yet the authorities began to patronize the theater.

1917 and the following years gave prerequisites to the qualitative changes in the director's and actor's art in the Far East due to at least two reasons: giving lower priority to the commercial nature of theatrical life; with an experimental change of the social structure, with passionate upsurge of social and political origins, new conditions for the passionate outburst in all areas of life appeared, and first of all - in art.

Gradually, in the public and the creative intelligentsia's minds the dreams of their own dramatic theater started to form, in particular from the beginning of the 1930s. "The necessity for establishment of a highly artistic theater in Khabarovsk took shape a long time ago. We need a theater that would meet the growing cultural needs of the working audience, could mobilize the public to active participation in socialist construction", was written in the regional newspaper in October 1933.

Intensified talks about the theater started in the spring 1933. City Council gave the instruction to organize stationary theater in Khabarovsk. But "the cost cards differed from the plans drawn up to meet the increasing cultural demands to the theater." In summer the already appointed director of the theater went to Moscow to recruit the staff. But he did not have sufficient funds, contracts were made with great difficulty, and when it was necessary to back them with advance payments, there was no money. The City Council did not answer the director's telegrams. When 
the money finally came, some actors had already gone, others had to wait until the autumn, and it was necessary to pay penalty costs for that, and those who got to Khabarovsk were out of work: the Department of Public Education of the Far Eastern region that was in charge of "culture and education" of the institutions decided to "relocate" the theater to Blagoveshchensk. In other words, "from its cradle" the Khabarovsk Theatre of Drama faced with the usual administrative bungling. But, despite all these troubles, the public voice was firm: "There can and should be theatre in Khabarovsk".

For seven years in Khabarovsk, the capital of the unprecedented huge Far Eastern region, Theatre of Musical Comedy had been successfully working, Regional Miners' Theater was organized in 1934, in 1937 - the Special Far Eastern Army Theater (that is, the Red Army Theatre), and in 1942 - the Youth Theatre. Yet theatrical Khabarovsk was content with "patronage assistance" of the professional drama theaters of Moscow and Leningrad, although the main purpose of the capital's "theatrical landing" was cultural service of the huge naval garrison of the Far East (Special Far Eastern Army and Pacific Fleet).

During the Great Patriotic War 13 professional local theaters worked in the Far East, among them 3 drama theatres that were located in the territory of Khabarovsk krai. There was no Drama Theater in Khabarovsk. Only Khabarovsk Regional Propaganda Theater actively performed with the genres of small stage forms. One of the first among its so-called "Defense Programs" was the program "Fire to the Enemy", which consisted of small one-act plays and dramatizations.

In 1941-45 Alexandrovsky-on-Sakhalin Oblast Drama Theatre, Blagoveshchensk Drama Theatre, Birobidzhan Drama Theatre named after L.M. Kaganovich, Vladivostok Drama Theatre named after A.M. Gorky, Kamchatka
Oblast Drama Theater, Komsomolsk-on-Amur Puppet Theater, Magadan Music Theater, Nanai National Theatre, Nikolayevsk-on-Amur Drama Theatre, Petropavlovsk-on-Amur Puppet Theater, Khabarovsk Theater of Musical Comedy, Khabarovsk Puppet Theater and Khabarovsk Regional Propaganda Theater performed in the Far East.

The war caught the Central Puppet Theater headed by S.V. Obraztsov on tour in Khabarovsk. For 3 years (1940-1943) the Leningrad New Theatre worked in the Far East, in 1942 Moscow Satire Theater was on tour in the Far East (Dobrovol'skaya, 2006).

But the Great Patriotic War triumphantly ended and the Soviet government decided to create Drama Theatre of the first group in Khabarovsk that was capable of solving complex and critical creative tasks. Already at the end of 1945 the necessary equipment and costumes were sent from Moscow. Work on the theater opening especially intensified in early 1946, beginning with the dawn and finished late at night. Actors who were recruited to the troupe refused their weekends. Auxiliary departments - wardrobe, technical and scenery were opened.

The building for the theater was chosen among the already existing buildings. It was the NKVD club of cultural activities. Eddie Rozner and Lidia Ruslanova imprisoned in the local camps once played in it. These were great concerts for the NKVD workers. Before the revolution the garden of Alekseevskaya girls' school was located in this building on Muravyev-Amursky street. And in 1929 on the place of the garden, where satin shoes of young girls used to tread, a building for cultural activities of security officers began erecting. And then this architectural structure welcomed its first spectators in the walls of the Theatre of Drama.

On 16 March 1946 a team of professional actors received the status of the Regional Drama 
Theater and official opening of the new cultural institution took place.

The first stage of the Khabarovsk Regional Theatre of Drama activity certainly cannot be given a positive evaluation, as it was still a long way to sustainable progressive tendencies of dramatic art in Khabarovsk. But, nevertheless, during the birth of the dramatic activity in Khabarovsk from the end of the $19^{\text {th }}$ century to the rise of the professional theater in 1946 and its existence until 1952, specific experience was accumulated, the professional theatre environment was created. It was the creation of the professional theatrical environment in 1952 that laid the foundation on which drama theater rests even now, even though deep in the province, but with its own unique features in direction and acting work development.

Thus, we return to the idea that a "big" and "strong" personality, a director, or an artistic director who is able to establish a repertoire policy and build general tendencies of its development within the troupe, should be in the basis of the theater aesthetics and its organizational parts.

In the autumn 1962 the collective of the Khabarovsk Regional Theater of Drama was headed by such a man, a new artistic director director, the Honoured Artist of the Armenian SSR Yan Tsitsinowsky.

The first work of Yan Tsitsinowsky in Khabarovsk was a play "The Ward” by S. Aleshin. It was followed by the play, which became the main premiere of the season "The Third Pathetic" by N. Pogodin. L. Eremeev was the director of the play, and it was the right and well-thought move of the new artistic director: a lot of people still had in the memory the play, which had a great response both from the public and from the local critics, staged by this master - "Tsar Fyodor Ivanovich". M. Khrabrov was given the leading role in "The Third Pathetic", who played
V.I. Lenin's role in details and accurately, thus contributing to playing Lenin in the Soviet era.

At the end of his first season in Khabarovsk Yan Tsitsinowsky staged "King Lear" by Shakespeare that can be also mentioned as a milestone work of the Khabarovsk Regional Theater of Drama.

This period is characterized by the active touring activity of the theater. Troupe spent the summer of 1963 in Chita. Before the performance the theater director G. Sashchenko talked about seventeen year history of the theater. "Gradually creative staff which today determines the theater direction, its possibilities and creative image was formed. Today our collective does not anymore satisfied with the external signs of the theatre success: positive reviews and good attendance" (Tikhookeanskaia Zvezda, 1963). In the article published in the leading regional newspaper to the beginning of the season of 1963-64, the director of Khabarovsk Regional Theater of Drama emphasized certain principles that have a positive impact on the theater activities. Here he mentions the search for new forms, the desire to create an original repertoire, which distinctive feature is ideological commitment.

According to the article "... Coming of a new theater director - N. Okhlopkov's disciple - Yan Tsitsinowsky" contributed to all these positive changes (Teatr, 1966).

The current and following seasons were marked by a huge number of visiting performances. Thus, the theater tour in Komsomolsk-on-Amur and, as it was mentioned above, in Chita lasted for 70 days. They were so commercially successful that a financial plan was exceeded over and above. During the tour the troupe continued to work on the plays and did not stop rehearsals. In this way a play "Mashenka" was prepared.

In the season of 1963-64 B.I. Ilyasov and A. Ilyasova came to the troupe. B. Ilyasov produced Tour's play "Escape from the Night", playing 
the role of the writer Kosogorov in it, which prototype was A. Kuprin. B. Shavrin created a new play - "Plakhov's Family", in which staging Yan Tsitsinowsky was engaged.

During this season, the troupe was on tours in the Amur Oblast and Buryatia, where the premiere of the play "Ivanov" by Chekhov (director Yan Tsitsinowsky) took place, and in which the director united drama and vaudeville.

There were innovative trends within the repertoire. The Khabarovsk Regional Theatre of Drama was the first in the country that staged the play by, as they said then, a progressive Irish playwright Sean O' Casey “The Bishop's Bonfire." The premiere took place on 26 December 1964. Yan Tsitsinowsky also staged a satirical comedy of the Greek writer D. Psafas "A Liar Is Required", a performance dedicated to the $20^{\text {th }}$ anniversary of the Victory "Stones in the Palm" by A. Salynsky and "Rage" by E. Yanovsky. The whole troupe of the collective was occupied in the play "Rage", and in this play a precious quality of the collective which is called "scenic ensemble" was particularly evident. Emotional content and the romantic high spirits are certainly observed here.

The theatre prepared the following performances: "104 Pages About Love" by E. Rodzinsky (directed by G. Wogau), "My Poor Marat" by A. Arbuzov (directed by Baltruљaitis) and "The Fool" by Lope de Vega (directed by G. Wogau).

Apart from the artistic director, G. Oganesyan, E. Skliar, A. Privman and A. Nikitin were engaged into productions in 1965-68. L. Eremeev, invited from Moscow and actor B. Ilyasov continued to stage performances. B. Stepin was the art director.

The Theatre of Tsitsinowsky period had both actors and author's direction. The actors who already had enough experience and invited directors were engaged in staging. This "mixture of aesthetics" was an interesting experience for the whole team, this approach to staging created its specific and particular way of creative development for Khabarovsk drama.

The Khabarovsk Regional Theatre of Drama in the period of 1962-68, the Khabarovsk Theatre of Drama of the period of Yan Tsitsinowsky's artistic leadership reached its highest peak: it was the period of the most brilliant creative innovations, strong author's and actors' direction, the broadest geographic and very successful touring, the period when real actors "stars" sparkled in the team, it was perhaps the only period when in Khabarovsk they not just talked about the Stanislavsky system, but worked with the Stanislavsky system, it was the period of the series of stage productions, which would be examples for the next compositions and generation of the troupe, it was the period when the genre field became the most widely spread - both for the plays chosen for productions and their stage productions.

It is significant that the period of the mid1960 s is most frequently mentioned by our experts-informants and the theater itself as a "golden age" of the Khabarovsk Regional Theatre of Drama (see "History" of the official website of the Khabarovsk Regional Theatre of Drama (Sait Habarovskogo..., 2008).

Finishing the story about the work of the master of scenic art Yan Tsitsinowsky, we can say with confidence that his work was a precious experience not only for himself, but for the whole creative team. His work as a director became milestone in the theater life. With their artistic management the concept of direction in the theater became more specific and clear. Actors started to regard their own work more seriously and professionally and started actively using Stanislavsky system in their work.

And speaking of provincial theater in general, it should be noted that its development has its own specific features, but the core, the 
foundation on which any professional theater is based is the same. This basis is not tied to the geography of the theater; it is tied to the aesthetic and educational functions. And if we mark an active and positive development in the history of the theatrical business in the Far East and in Khabarovsk, we are always faced with the personality that comes into the team and on the basis of this team creates powerful ideological and aesthetic message.

\section{References}

Teatr i iskusstvo (1897). [Theatre and Art], 30, 543.

Ivanov, A. (1994). Doroga dlinoju v vek: 100 let teatru dramy Habarovska [A Road That Lasts a Century: 100 Years to Khabarovsk Theatre of Drama]. Khabarovsk, 245.

Teatr i iskusstvo (1909). [Theatre and Art], 5, 104.

Teatr i iskusstvo (1908). [Theatre and Art], 6, 123.

Teatr $i$ iskusstvo (1910). [Theatre and Art], 7, 167.

Dobrovol'skaya, I.V. (2006). Kogda govoriat muzy, pushki molchat: Iskusstvo na Dal'nem Vostoke v gody Velikoi Otechestvennoi voiny [When Men Speak Guns Keep Silence: Art in the Far East During the Great Patriotic War], In Slovesnitsa iskusstv [Philology of Art], 18, 110-112.

Tikhookeanskaia Zvezda (1963). [The Pacific Star], In Pered nachalom sezona (redaktsionnaja stat'ia) [Before the Season Beginning (Editorial)]. 25 October, 3.

Teatr (1966). [Theater], In Rabota teatra dramy (redakcionnaja stat'ia) [Work of the Theatre of Drama (Editorial)], 12, 42-47.

Sait Habarovskogo gosudarstvennogo instituta iskusstv i kul'tury [Website of Khabarovsk State Institute of Arts and Culture]. (Accessed 03 August 2008). http://www.arts.fromru.com/

\section{Провинциальный театр:}

\section{проблемы становления и развития}

театрального искусства в Хабаровске

\section{С.В. Листопадов}

Хабаровский государственный институт культуры Россия, 680045, Хабаровск, ул. Краснореченская, 112

Статья посвящена особенностям становления и развития провинцильного театра. Проблемы, затронутые в статье, рассматриваются на примере театрального искусства в городе Хабаровске в иелом и в частности на примере развития Хабаровского краевого театра драмы и комедии. Автор приходит к выводу, что создание к 1952 г. профессиональной театральной среды в Хабаровске заложило фундамент, на котором и сейчас зиждется драматический театр со своими неповторимыми особенностями в развитии режиссуры и актерского творчества.

Ключевые слова: искусство, театр, провинииальный театр, драматический театр, режиссуpa, penepmyap.

Научная специальность: 17.00.00-искусствоведение. 